\title{
Introduction: Questions of Space and Place in Scholarship on Modern Hungary ${ }^{1}$
}

\section{Steven Jobbitt and Róbert Győri}

Abstract: Reflecting on both the personal and intellectual factors that influenced this thematic cluster on space, place, and the making of modern Hungary, the authors situate themselves within the history of the post-socialist revival of geography in Hungary, outlining in particular emergent fields of study and new schools of thought that have transformed geographical research and teaching over the last decade. Having drawn together historians and geographers working in Hungary, Canada, and the United States, Part I of this two-part cluster represents an effort to bring different disciplinary streams and academic cultures into contact with one another, and has provided the authors with an opportunity to better survey the state of a very broad and dynamic field of study, and to identify and begin to address lacunae in their collaborative work.

Keywords: History of Hungarian Geography; Space and Place; Geography and Theory; Geography and Culture

Biographies: Steven Jobbitt is assistant professor of modern European history at Lakehead University in Thunder Bay, Ontario. He is technical editor of Hungarian Cultural Studies, and was recently appointed to the editorial board of Földrajzi Közlemények ['Geographical Review']. He has published on the life and work of Ferenc Fodor, a conservative-nationalist Hungarian geographer, and is currently working on projects dealing with Hungarian imperialism in the Balkans at the beginning of the twentieth century, and the history of the radical right in Hungary since 1989.

Róbert Győri is associate professor and in-coming Chair of the Department of Social and Economic Geography at Eötvös Loránd University, Budapest, and head of the Tibor Mendöl Geography and Earth Sciences Workshop at the Eötvös József Collegium of ELTE. He received his Ph.D. in geography from the Eötvös Loránd University (ELTE) in 2006 and habilitated at the same university in 2014. His research fields include historical geography, urban geography, and the history of geographical knowledge. His current research focuses on how science was controlled and managed by a totalitarian regime, and how Hungarian geography in particular was crushed as a result of Sovietera transformations.

${ }^{1}$ Róbert Győri's research for this paper was supported by a János Bolyai Research Scholarship from the Hungarian Academy of Sciences. 
Jobbitt, Steven and Róbert Győri. "Introduction: Questions of Space and Place in Scholarship on Modern Hungary." Hungarian Cultural Studies. e-Journal of the American Hungarian Educators Association, Volume 7 (2014): http://ahea.pitt.edu DOI: 10.5195/ahea.2014.176

\section{Introduction}

The story behind this thematic cluster on space, place, and the making of modern Hungary is as much personal as it is scholarly.

The story for both of us begins on a cool November morning in 2003 when, as a doctoral student from the University of Toronto, I made my way to the Center for Regional Studies of the Hungarian Academy of Sciences (then located in Budapest's Castle District) to meet with Róbert Győri, a young Hungarian geographer also in the process of researching and writing his dissertation. On the recommendation of historians Ignác Romsics and Balázs Ablonczy, Robi had kindly agreed to meet with me to discuss a possible research topic on the history of Hungarian geography. Having read as much as I could on Hungarian history itself, I was keenly aware of the importance of geography to Hungarian politics and identity formation, especially in the wake of World War I, when Hungary lost a full two-thirds of its prewar territory. I was steeped, as well, in cultural theory, and in the pivotal works of Larry Wolff (1994), Maria Todorova (1997), and Milica Bakić-Hayden (1995), three scholars whose respective studies on Eastern Europe and the Balkans marked some of the earliest forays into the imagined, philosophical geographies of Europe's eastern "other" (see also Hofer 1994). I was certain, also, that lurking somewhere in the archives would be at least a box or two of documents that would help me to begin tracing the links between nationalism, modernity, geographical production, and the negotiation of identity and self. What I was lacking, however, was a clear understanding of the history of Hungarian geography as a discipline, and the history and workings of geographical science more generally.

With his impressive knowledge of the archives, historical geography, and the history of Hungarian geography more generally, Robi was definitely the right person to talk to. Our first encounter in November 2003 led to a series of bi-weekly chats about my research. These discussions not only laid the groundwork for my dissertation on the life and work of the interwar Hungarian geographer Ferenc Fodor, but also marked the beginning of a friendship which, happily for both of us, was rekindled in 2012, and which has led to a collaborative and increasingly productive scholarly partnership (the early fruits of which we hope will become evident in this thematic cluster).

In many ways, Robi's scholarly path was almost the opposite of mine. Indeed, it wasn't an incomplete knowledge of the history of Hungarian geography that hampered him in his scholarly pursuits, but rather the lack of an adequate analytical framework to tease out the interconnected meanings of what he was studying. And so it is in the midst of his efforts to fill this theoretical gap in his scholarship that we pick up his story a few years later, in January 2008, when he went to Edinburgh, Scotland on a three-month research trip. Having defended his thesis two years earlier, he was seeking new inspiration in order to further develop his historical geographical research. Once a flourishing field in Hungary, historical geography had ceased to exist shortly after World War II, and was only resurrected by a handful of devoted scholars in the 1980s (Frisnyák 1990; see also the discussion on the work of Zoltán Hajdú below). The resurgence of Hungarian historical geography, however, had no connections with contemporary international trends, but instead was based on the revival of seminal works of key interwar Hungarian geographers (for example Fodor 1935, Mendöl n.d. [1938], and Bulla n.d. [1938]; for a critical discussion of this revival see Gyimesi in this issue). The same trend could be seen for almost all branches of post-socialist Hungarian human geography as well. And since studies in 
Jobbitt, Steven and Róbert Györi. "Introduction: Questions of Space and Place in Scholarship on Modern Hungary." Hungarian Cultural Studies. e-Journal of the American Hungarian Educators Association, Volume 7 (2014): http://ahea.pitt.edu DOI: 10.5195/ahea.2014.176

the humanities had been more or less sealed off from Western academia for decades, it was (and in many respects still is) hard to keep abreast of recent theoretical and methodological innovations.

As Robi gladly admits, it was precisely for these reasons that his journey to Scotland proved to be such a tremendous experience. Guided by Edinburgh-based historical geographer Charles Withers, he was informed about how human geography (and with this also historical geography and the history of geography) had been transformed since the 1970s by critical theory, feminism, postmodernism, poststructuralism, and so on. As Robi learned, writing the history of geography is no longer an internalist, presentist, or essentialist project (Livingstone 1992). Instead, geography as a discipline and practice is informed by, and works in partnership with, science and technology studies, the sociology of scientific knowledge, actor-network theory, and Foucauldian genealogy (to name only a few approaches that are currently popular amongst historians of geography) (Withers 2001, Livingstone 2003, Barnes 2004, Withers 2010). When Robi returned from his first Edinburgh visit, he embarked upon a new project: to inform his young colleagues and students about these theoretical developments, and to write studies for both Hungarian and non-Hungarian audiences using some of these approaches.

In recent years, the Mendöl Workshop of Geography and Earth Sciences at the Eötvös Collegium, ELTE, has become one of the most important places for work on the history of Hungarian geography. Founded at the end of the nineteenth century, the Eötvös Collegium was modelled on the École Normale Supérieure in Paris. It was the central place for the training of the elite in Hungary, and the best Hungarian geographers during the interwar period were educated there. After World War II, the policies governing communist science were hostile to this institution (which the communists did not trust), which led to its dissolution in 1950. Although the reorganization of Collegium started already in the late 1950s, it did not have a Geography and Earth Sciences program until the late 1990s. The Mendöl Workshop started its activity in 1999, and in accordance with the Collegium's philosophy, the workshop organizes courses that set high academic standards on topics absent from the normal university curricula of ELTE. Serving as the head of this small scholarly community since its foundation in 1999, Robi has ensured that critical work on the history of geography continues to gain in importance. The informal cluster of young geographers who are today interested in critical approaches to the history of geography, and who are now lecturers at the Collegium, consists of the alumni of the Mendöl Workshop. Their research focuses primarily on interwar geography (Czirfusz 2012, 2014; Györi 2001, 2002, 2009; Gyuris 2009, 2014), and on socialist Hungarian geography, a topic that has been taboo until recently (Czirfusz 2010, Györi 2011, Győri and Gyuris 2012, Gyuris and Győri 2013, Heffernan and Győri 2014, Gyimesi 2011, 2014). The Mendöl

Workshop has also organized several conferences in recent years: a conference on the influential interwar geographer Ferenc Fodor in 2012 (Győri 2012), an international summer workshop (Geography and Nation Building in Central and East Central Europe) in 2013 (Tolnai 2013, Palaczki 2013), and a conference on the history of geography at the Eötvös Collegium in 2014. The results of our most recent research were summarized in a collection of essays published in 2014 (Győri 2014, Probáld 2014). 
Jobbitt, Steven and Róbert Győri. "Introduction: Questions of Space and Place in Scholarship on Modern Hungary." Hungarian Cultural Studies. e-Journal of the American Hungarian Educators Association, Volume 7 (2014): http://ahea.pitt.edu DOI: 10.5195/ahea.2014.176

I myself re-entered this story in 2012, when, after eight years of no contact between us, Robi invited me to come to Budapest to take part in the conference on the life and work of Ferenc Fodor (to be honest, I was very surprised to discover that I was considered one of the leading experts on him; indeed, my own relative expertise was as much a function of the dearth of scholarship on interwar geography as a whole as it was a result of my own scholarly accomplishments). The conference on Fodor rekindled discussions that Robi and I used to have when we were both Ph.D. candidates, and has since led to collaborations that have seen the mutual translation of each other's work, and also to the organization of the international workshop (co-organized also with Ferenc Gyuris) held at the Eötvös Collegium in summer 2013. Dedicated to critical studies on the relationship between geography and nation building in Central and East Central Europe, the conference brought together geographers and historians from Hungary, Scotland, England, Germany, Italy, France, Canada, and the United States, and only reinforced our desire to pursue collaborative, interdisciplinary (and increasingly transnational) scholarship further.

Built upon the foundations of a friendship and research partnership that began in 2003, and which has intensified significantly since 2012, this cluster reflects a twofold desire on our part to bring Hungarian geographical scholarship to a broader international audience, and to encourage more generally the continued application of a variety of theoretical approaches to the study of Hungarian history and geography. Our hope is that collaborative projects like this will help to push the boundaries of knowledge on, and critical analysis of, the interconnected fields of historical geography, on the one hand, and the history of Hungarian geography and geographical thinking, on the other. Focusing not only on the discipline and practice of geography itself, but also on the ways that the negotiation and re-negotiation of identities is linked to spatial conceptions of nation, community, and self, our end goal is to provide new - and we hope useful - perspectives on modern Hungarian ways of "seeing" and "being."

\section{The Articles}

Our cluster opens with Andrew Behrendt's study "Educating Apostle's of the Homeland: Tourism and Honismeret in Interwar Hungary." Mirroring the "spatial turn" in critical Heimat ['homeland'] studies in Germany (see for example Eigler 2012), Behrendt examines the efforts of interwar geographers, pedagogues, and tourist promoters alike as they attempted to transform Hungary from "a vague concept" or mere outline on a map into "a collection of places and distinct sites invested harmoniously with national and personal meaning." Focusing on an educational initiative called the School Excursion Trains of the Capital City of Budapest (Budapest Székesfóváros iskolai kirándulóvonatai) (1934-1942), Behrendt's study looks critically at the convergence of various commercial, political, and pedagogical interests, and in so doing provides valuable insight not only into the discourse and practice of Hungarian honismeret ['knowledge of the homeland'] between the wars, but also into what exactly it was that Hungarian youth were expected to learn about themselves, their nation, and the geographical space(s) of the country they lived in.

Behrendt's original and very well-researched study serves as a particularly apt starting point for our thematic cluster as he clearly engages with and explains some key conceptual differences between "space" and "place." Building upon Yi-Fu Tuan's now-seminal definition of "place" as a "space" that people have gotten to "know" and imbue with deeper meaning, 
Jobbitt, Steven and Róbert Győri. "Introduction: Questions of Space and Place in Scholarship on Modern Hungary." Hungarian Cultural Studies. e-Journal of the American Hungarian Educators Association, Volume 7 (2014): http://ahea.pitt.edu DOI: 10.5195/ahea.2014.176

Behrendt provides a very useful illustration of the various social, cultural, political, and economic anxieties that fuelled interwar attempts by Hungarian nation-builders to turn the vague physical and conceptual spaces of post-Trianon Hungary into knowable places, ones which were in themselves as much "constructed" and "imagined" as they were real.

Given the constructed and thus deeply political nature of interwar imaginings of nationalist "places," it comes as no surprise that the meaning of Hungarian landscapes and cityscapes has been highly contested throughout the modern period. Focusing on the often heated debates waged between populists and urbanists in the interwar period, Richard Esbenshade's "Symbolic Geographies and the Politics of Hungarian Identity in the 'Populist-Urbanist Debate,' 1925-44" explores how spatialized notions of nation, race, and community were mobilized by intellectuals on both the left and the right as they struggled to define and shore up notions of Hungarian nationalism and identity between the wars. Building on the tradition of theorists like Benedict Anderson (1991), Thongchai Winichakul (1994), and Franco Moretti (1998), Esbenshade unpacks the competing symbolic geographies mobilized by the main players on both sides of this debate, arguing that geographical discourse and imagery were deployed not only to describe Hungary's putative national character, but also to legitimize one's own position while simultaneously delegitimizing the position of an opponent. Resisting a simplistic reading of this symbolic and discursive deployment, Esbenshade demonstrates that these spatial references were not just political, but also represented a sincere and ultimately critical attempt to map out and understand Hungary's position both regionally and globally.

Running through and largely defining the interwar populist-urbanist divide were competing theories regarding the cultural roots and "proper" geopolitical orientation of the nation. Tapping directly into a topic that has received much attention since the publishing of Said's seminal book Orientalism (see for example Maxwell 2011), Esbenshade investigates the different ways that conceptualizations of "east" and "west" informed the thinking of populist and urbanist intellectuals alike, and comes to the conclusion that the shifting and inherently relative usage of these spatial categories points to a "postmodernization" of geographical discourse in interwar Hungary, thus shedding new light on the "fluid mental maps" that situated Hungary between "east" and "west," "Asia" and "Europe," and "tradition" and "progress."

In "East and West in Modern Hungarian Politics," Katalin Rac continues the discussion started by Esbenshade by pointing out the deep historical roots, as well as the contemporary political significance, of the role that conceptualizations of east and west have played in nationalist and state-building discourse from the medieval period to the present. Building on a practice that she identifies in her dissertation as "self-Orientalism" (Rac 2014), and echoing the insights of ground-breaking studies that have explored the way Orientalist thinking and practices have been understood and instrumentalized by intellectuals, nation builders, and ordinary people alike in the Balkans (see for example Bakic-Hayden 1995, Todorova 1997, and Neuberger 2004), Rac provides a very useful overview of constructions (and manipulations) of "east" and "west" from the pre-modern period to the present. Focusing primarily on István Széchenyi's nineteenthcentury conceptualization of Hungarians as an "eastern nation" ['kelet népe'], as well as on the current prime minister Viktor Orbán's symbolic reorientation from "west" to "east" since coming to power in 2010, Rac navigates adroitly through complex conceptual and historical terrain, and in doing so underlines the importance of understanding "east" and "west" as discursive categories deployed strategically by political power at different points in Hungarian history. 
Jobbitt, Steven and Róbert Győri. "Introduction: Questions of Space and Place in Scholarship on Modern Hungary." Hungarian Cultural Studies. e-Journal of the American Hungarian Educators Association, Volume 7 (2014): http://ahea.pitt.edu DOI: 10.5195/ahea.2014.176

With Ferenc Gyuris's article "Human Geography, Cartography, and Statistics: A Toolkit for Geopolitical Goals in Hungary until World War II," we return once again to the interwar period, and to a study which is situated squarely within the broader post-1989 revival of historical and cultural geography in Hungary. Writing as one of the core members of the Mendöl Workshop noted above, Gyuris explores the relationship between power and geographical production from the beginning of World War I to the end of the interwar period. Focusing in particular on map making, Gyuris skillfully unpacks the conceptual and technical "toolkit" available to geographers and politicians as they made their cases at the Paris peace talks at the conclusion of the war, and as they struggled to respond to the postwar territorial reordering of central and east central Europe. Situating his study in a comparative, transnational context, Gyuris joins the ranks of a growing number of scholars who show us just how effective and crucial it is to look "across" borders as we seek to better understand the various forces and events that have given shape to the history and geography of this region (see for example Melegh 2006, Case 2009, and Blomqvist, Iordachi, and Trencsényi 2013). Moreover, by illustrating how geographers from different countries employed exactly the same data to produce contradictory conclusions, Gyuris's comparative, transnational approach forces us to think very critically about the way science can be manipulated by power, and the active role that scholars themselves play in this process. In the final analysis, Gyuris contends that a critical awareness of geography's past can and should lead to a heightened self-awareness on the part of present day practitioners of geographical science. Like all scholars, he argues, geographers need to be aware of their embeddedness within socially, culturally, and politically constructed regimes. Having shown quite clearly how the discipline of geography became "militarized" in the first half of the twentieth century, Gyuris concludes that we need to resist a potential "re-militarization" of our discipline, and be sure that the knowledge we produce is used for progressive and peaceful, rather than destructive and narrow, ends.

Zoltán Gyimesi's study picks up where Gyuris's leaves off, not just chronologically, but morally and conceptually as well. Also a member of the Mendöl Workshop and other research groups doing new and exciting work in critical and cultural geography in Hungary, Gyimesi's study offers a critical reading of the problems associated with an uncritical resurrection of geographical thinkers and thinking from the past (and in particular from the interwar period). Reflecting on the resurgence of historical geography in the wake of the collapse of state socialism in 1989, Gyimesi deconstructs the problematic republishing of Tibor Mendöl's Bevezetés a földrajzba ['Introduction to Geography'] which was first published in 1951, and which was resurrected and reprinted with slight (but ultimately crucial) revisions in 1999. Excavating the internal tensions of a book written in the 1950s by a Horthy-era geographer attempting to force his "traditionalist" viewpoints into a Marxist-Leninist framework, Gyimesi cleverly exposes the complex "dual narrative" that informed the writing and rewriting of the original text, and is critical of the failure on the part of its two rehabilitators to identify and interrogate the Eurocentric, rationalist-imperialist character of the original. Speculating on the motivations that may have existed behind the republishing of Mendöl's work, Gyimesi concludes his fearless study just as Gyuris does with some pointed and very timely observations that lead us to reflect critically on the relationship between scholarly production and power, and on our own moral and political obligations as public intellectuals. Situating his reading of Mendöl's text and its republication within an impressive body of critical literature that engages recent developments 
Jobbitt, Steven and Róbert Győri. "Introduction: Questions of Space and Place in Scholarship on Modern Hungary." Hungarian Cultural Studies. e-Journal of the American Hungarian Educators Association, Volume 7 (2014): http://ahea.pitt.edu DOI: 10.5195/ahea.2014.176

in post-colonial theory, post-socialist theory, world-systems theory, and Marxism, Gyimesi's study provides a good example of the necessity for, and the value of, theoretical approaches to geography, and to questions of space and place more generally. Moreover, Gyimesi's lengthy list of works cited (roughly ten pages in total) would be a good place to start for anyone interested in this field of study, and would be especially useful for students of Hungarian history and geography keen on integrating theory into their work.

Of course, not all scholarship on space, place, and the making of modern Hungary has to be articulated in the language of critical theory in order for it to be either useful or interesting to scholars working in the field. In his article on a series of pocket atlases published in Hungary between 1913 and 1919, Zoltán Hajdú offers an important overview of a little-studied genre of geographical knowledge-production during the war, one that provides keen insight into the role that the Magyar Földrajzi Intézet ['Hungarian Geographical Institute'] played in generating and communicating social, historical, geographical, and geopolitical ideas both to Hungarian secondary-school students and to the general public. Focusing in particular on the atlases published during the war itself, Hajdú's study (published in this issue as a Research Note), opens up yet another critical window on the relationship between cartography and state building, and with this also on the central role that maps played in the dissemination of nationalist ideas and nation-building propaganda. As Gyuris shows in his article, this relationship is by no means a neutral or innocent one, and Hajdú's careful reading of these texts helps to lay the groundwork for future theoretical analysis and comparative study along these lines.

One of the more significant observations that Hajdú makes concerns the active role that geographers and geographical bodies like the Magyar Földrajzi Intézet played in promoting the imperial ideas and colonial ambitions of Hungary, especially during the war. Shedding some important light on a question that has received growing attention from both historians and geographers alike in recent years (see Gyuris in this issue, see also Hajdú 2007, Jobbitt 2008b: 78-93, and Rac 2014), Hajdú's study of the pocket atlas series clearly outlines both the nature and the scope of Hungarian imperialist thinking in the first two decades of the twentieth century, reminding us, as the historian Robert Nemes does, that in the pre-Trianon period, Hungarian nationalists "pursued their aims within an imperial framework" (Nemes 2005: 8). Far from being a mere extension of Austrian imperialism, what we are shown from the texts, and what we know from the emerging body of scholarship in the field, is that Hungarian state building was driven by a colonial-imperial vision that was very similar to the vision of any of the other European imperial powers of the time (see also Gyimesi in this issue). Though at least some in Hungary may have entertained hopes of establishing a colony in Africa (see again Gyuris in this issue), Hungarians increasingly turned their attention towards the Balkans by the end of the nineteenth century, and to a lesser extent to their historical "civilizing" mission in the Carpathian Basin (especially after 1914). As Hajdú shows, the instability created by the First and Second Balkan Wars (1912-1913), followed by the geopolitical opportunities opened up by World War I, provided Hungarian state and nation builders with a situation in which they could more fully imagine and act upon visions of a much-expanded Hungarian "empire." Illustrating how this vision was articulated pedagogically, Hajdú's study helps us to better understand one of the important ways that Hungarians had begun to imagine (or, rather, reimagine) themselves spatially, culturally, and politically in the years leading up to the end of the war in 1918. 
Jobbitt, Steven and Róbert Győri. "Introduction: Questions of Space and Place in Scholarship on Modern Hungary." Hungarian Cultural Studies. e-Journal of the American Hungarian Educators Association, Volume 7 (2014): http://ahea.pitt.edu DOI: 10.5195/ahea.2014.176

Hajdú's contribution to research on the history of Hungarian geography cannot be underestimated. He was one of the few geographers who turned their attention to the history of geography in the last decade of socialism, and in so doing he pioneered the rethinking and revision of some important topics in the history of Hungarian Stalinist geography. Key contributions in this respect included critical work on the the brutal policy concerning the scattered farms of the Great Hungarian Plain in the late 1940s and 1950s (Hajdú 1990-91, 1992), as well as on communist attempts at the transformation of nature (Hajdú 2006). In addition to his groundbreaking works on the history of socialist geography, Hajdú has published articles on the late-nineteenth century "imperialist" research that Hungarian geographers conducted in the Balkans (Hajdú 2007), as well as on the Trianon peace treaty (Hajdú 2000), and on the work of interwar Hungarian geographers (Hajdú 2008). Though his works are informed neither by critical theory, nor by poststructuralist or postmodern thought, his scholarly output is based on extensive archival research that in itself will continue to be invaluable to any scholar interested in the history of Hungarian geography in particular, and questions of space and place more generally.

\section{Obvious Lacunae and Other Loose Ends: Looking Ahead to Part II of Our Cluster}

Anyone well-versed in the broad field of study that we have chosen to engage in here will recognize that Part I of our thematic cluster is by no means a complete or exhaustive survey of the work that either has or should be done on the rich and very complex relationship between space, place, and the making of modern Hungary. In some cases this is simply a function of potential authors being unable to commit to the first half of this project, and we sincerely hope that, by expanding our work into 2015, we will be able to publish papers in Part II that couldn't be completed for our 2014 issue.

One glaring lacuna that needs to be addressed is the relationship - both discursive and in practice - between gender and space. Pioneering studies by cultural anthropologists like Martha Lampland (1994), sociologists like Gábor Gyáni (1989, 2002), and geographers like Judit Timár and Éva Fekete not only indicate a direction we need to take our work in, but also provide a clear framework for the critical discussions we need to have. As Timár and Fekete (2010) suggest, this doesn't simply mean including gender as an analytical category of study; it also entails an active "seeking out" of women's voices, and with this the creation of critical spaces for both women and feminist theory in the work we do collectively and individually. By broadening our approach in the ways demanded by the existing scholarship in this field, we stand to gain a more nuanced and thus complete understanding of the impact that spatial constructions have on gender, and the role that gendered attitudes and performances have on the perception, creation, negotiation, and reformation of space and place. In this light, a more conscious focus on the relationship between masculinity and the interconnected categories of space and place is also needed. Though some work has no doubt been done on this (see for example Jobbitt 2008a, 2008b, 2011; see also Gyimesi in this issue) much more work lays ahead as we continue to probe both the macro- and micro-geographies of nation, community, family, and self.

In addition to addressing the question of gender, a fuller accounting of the role of space and place in the making of modern Hungary would do well to take into consideration an emergent body of scholarship that deals explicitly with race and ethnicity, in particular as this relates to the history and geography of ethnic violence and the Holocaust. Marius Turda's recent 
Jobbitt, Steven and Róbert Győri. "Introduction: Questions of Space and Place in Scholarship on Modern Hungary." Hungarian Cultural Studies. e-Journal of the American Hungarian Educators Association, Volume 7 (2014): http://ahea.pitt.edu DOI: 10.5195/ahea.2014.176

study, "Imagined Geographies of Race: Hungary and Romania,1900-1940" (2013), for example, builds on his earlier examination (2007) of biopolitics and nation building in interwar Romania, and forces us not only to think in a transnational and comparative way about racialized constructions of space and place, but also to consider more critically the role that geography has played in this process. Tim Cole's work on Jewish ghettos and Holocaust landscapes in Hungary during World War II $(2003,2011)$, in turn, encourages us to look seriously at Holocaust spaces as a legitimate and much needed category of historical and geographical analysis. As a pioneer of this field in Hungary, Cole's work fits into a growing corpus of critical studies that explore the spatial dimensions of genocidal violence, and which reveal the importance of "location" to an individual's experience of the Holocaust, and of racial and ethnic violence more generally (see Nemes and Unowsky 2014; Knowles, Cole, and Giordano 2014).

Also worthy of attention is a rather broad and well-established sub-field that investigates urban spaces, and with this the history, geography, anthropology, and sociology of cities and other forms of human settlement. This has a long tradition within Hungarian geography, with the classic works of scholars like Ernő Wallner (1958), Tibor Mendöl (1963), and Edit Lettrich (1968) now making way for new studies by scholars like József Benedek and Zsombor BartosElekes (2009), and Ágnes Erőss and Patrik Tátrai (2010). Pioneering works on the social, cultural, and intellectual history of the Hungarian city - and in particular Budapest-include Péter Hanák's 1998 The Garden and the Workshop (a work that is often read alongside Carl Schorske's seminal examination of fin-de-siècle Vienna (1981) and Judit Frigyesi's study of finde-siècle Budapest (1998)), as well as Robert Nemes's very engaging The Once and Future Budapest (2005, see also Gerő and Poór 1997). Gábor Gyáni’s work on both public (2004) and private $(1989,2002)$ spaces in Budapest once again provides important insight, not only into the lived experiences of city-dwellers and the social and material culture of Hungary's capital city, but also into the spatiality of social relations in a modern urban center undergoing a rapid process of modernization from the late nineteenth century to the beginning of World War II. Equally important to our evolving understanding of built-up spaces as social, political, cultural, and ideological constructs are studies that look specifically at cityscapes, and in particular at the architecture, monuments, and sites of memory that shape the urban experience (see for example Bucur and Wingfield 2001, Alofsin 2006, Thorstensen 2012, and Molnár 2013 reviewed in this cluster).

At the risk of creating a list that any one scholar would be hard-pressed to master fully, it is worth noting that space and place studies have also seen a growth in the study of borderlands (see for example Kürti 2001, Brown 2003, Davis 2011, Nemes 2012), and with this also the role that the demarcation and mapping of state borders in the early modern period played in the creation and evolution of national and imperial identities, and in turn also the generation of modern consciousness and subjectivities (see for example Fischer et al. 2010 reviewed in this cluster). One particularly bright light in this field is Madalina-Valeria Veres, a Ph.D. candidate in history at the University of Pittsburgh whose recent work (2012, 2014) on eighteenth-century cartography in the Habsburg empire lays the potential groundwork for culturally and theoretically engaged studies of similar processes in the Kingdom of Hungary. Drawing inspiration from works like Peter Sahlins's now-classic Boundaries: The Making of France and Spain in the Pyrenees (1989), and building directly on Valerie Kivelson's ground-breaking study of cartography and state building in seventeenth-century imperialist Russia (2006), Veres 
Jobbitt, Steven and Róbert Győri. "Introduction: Questions of Space and Place in Scholarship on Modern Hungary." Hungarian Cultural Studies. e-Journal of the American Hungarian Educators Association, Volume 7 (2014): http://ahea.pitt.edu DOI: 10.5195/ahea.2014.176

employs archival material gathered in Vienna and Paris to explore Austrian attempts to map out, and thus assert power over, the eastern border of the Habsburg Monarchy (for a similarly inspiring study on imperialist Russian cartography on its western border, see Seegel 2012).

Finally, recent theoretical studies like that by Eleftheria Arapoglou, Mónika Fodor, and Jopi Nyman (2014), coupled with the work being done by historians like István Kornél Vida (2013, see also his article in this issue) and Tibor Glant (2013, reviewed in this cluster), opens up the possibility for more concerted work on geographies of emigration and immigration, and for more critical studies on the role that migration and the emigrant/immigrant experience played in the making of modern Hungary. A big part of this story, of course, is the impact that emigration (for example in the nineteenth century, and then again after the 1956 revolution), and by extension also immigration (of Galician Jews at the fin-de-siècle, for instance, or ethnic Hungarians after World War I) has had on Hungarian landscapes and cityscapes, and thus also on the shifting cultural and social constructions of both space and place. Within this much bigger story is also the potential to explore more fully and explicitly the spatiality of identity formation, and the shifting subjectivities of the migrant "self." As Mónika Fodor argues in her recent study of the nineteenth-century Hungarian naturalist-cum-adventurer John (János) Xántus, travels to and in foreign spaces (in Xántus's case the American West) not only bring migrants and travelers into contact with new cultures, but also invite and/or force individuals "to consider [their] own ethnic backgrounds critically," and to "develop trans-ethnic attitudes to viewing the other" (Fodor 2014: 70). Fodor's examination of the opportunity, and even necessity, that travel itself provides to enact new performances of self speaks volumes to the fluidity of human identities and subjectivities, and suggests a need to look more closely at how these performances are rooted as much in space and place as they are in complex social, cultural, and psychological processes.

The more we write and talk about it, the more Robi and I realize that we have just begun to scratch the surface of an exciting and ever-expanding field of study, a field that both of us are deeply embedded in and hope to see grow in new and provocative ways. Our own interconnected stories - just like the stories behind many of the articles in this cluster-speak not only to the importance of rigorous cross-disciplinary collaboration, but also to the value of collective, theoretically-informed scholarship on a theme that no one scholar (or even discipline) could ever hope to do justice to on his or her own. With this in mind, we offer you a glimpse here into some of the work currently being done in the field, and promise to redouble our efforts in order to produce even more new works for Part II of our cluster forthcoming in 2015.

\section{Works Cited}

Alofsin, Anthony. 2006. When Buildings Speak: Architecture as Language in the Habsburg Empire and Its Aftermath, 1867-1933. Chicago: University of Chicago Press.

Anderson, Benedict. 1991. Imagined Communities: Reflections on the Origins and Spread of Nationalism. Revised ed. London and New York: Verso.

Arapoglou, Eleftheria, Mónika Fodor, and Jopi Newman, eds. 2014. Mobile Narratives: Travel, Migration, and Transculturation. New York and London: Routledge.

Bakić-Hayden, Milica. 1995. "Nesting Orientalisms: The Case of Former Yugoslavia." Slavic Review 54/4 (Winter 1995): 917-31. 
Jobbitt, Steven and Róbert Győri. "Introduction: Questions of Space and Place in Scholarship on Modern Hungary." Hungarian Cultural Studies. e-Journal of the American Hungarian Educators Association, Volume 7 (2014):

Barnes, Trevor J. 2004. "Placing Ideas: Genius Loci, Heterotopia and Geography’s Quantitative Revolution." Progress in Human Geography 28. 5: 565-595.

Benedek, József and Bartos-Elekes, Zsombor. 2009. "Symbolic Spatial Usage in the Historic City Centre of Cluj-Napoca." In Descriptio Transylvaniae. International Conference on History of Cartography and Historical Geography: Cluj-Napoca - Kolozsvár, April 24th25th, 2009. Ed. Boglárka Csiki and Zsombor Bartos-Elekes. Cluj-Napoca: Cholnoky Jenő Geographic Society - Babeş-Bolyai University, Faculty of Geography: 95-108.

Blomqvist, Anders E.B., Constantin Iordachi, and Balázs Trencsényi, eds. 2013. Hungary and Romania Beyond National Narratives: Comparisons and Entanglements. Oxford: Peter Lang.

Brown, Kate. 2003. A Biography of No Place: From Ethnic Borderland to Soviet Heartland. Cambridge, MA: Harvard UP.

Bucur, Maria, and Nancy M. Wingfield, eds. 2001. Staging the Past: The Politics of Commemoration in Habsburg Central Europe, 1948 to the Present. West Lafayette, IN: Purdue UP.

Bulla, Béla. n.d. (1938). "Hazai történeti földrajzunk múltja, jelene és feladatai” ['The Past, Present and Future Tasks of Hungarian Historical Geography']. In Emlékkönyv Szentpétery Imre születése hatvanadik évfordulójának ünnepére. ['Festschrift for the Sixtieth Birthday of Imre Szentpéteri']. Budapest: 312-334.

Case, Holly. 2009. Between States: The Transylvania Question and the European Idea During World War II. Stanford: Stanford UP.

Cole, T. J. 2003. Holocaust City: The Making of a Jewish Ghetto. New York and London: Routledge.

. 2011. Traces of the Holocaust: Journeying in and out of the Ghettos. Continuum.

Czirfusz, Márton. 2010. “A földrajztudományi mező müködése a hatvanas évek két kandidátusi védése alapján" ['The scientific field of geography in function, according to two CSc. defences in the 1960s']. In Geográfus Doktoranduszok X. Országos Konferenciája. Szeged, Magyarország, 2010.04.01-2010.04.02. ['Proceedings of the $10^{\text {th }}$ National Conference of PhD Students in Geography, Szeged, Hungary, 2010.04.01.-2010.04.02.']. Ed. Péter Bajmócy and Klára Józsa. Szeged: SZTE TTIK Gazdaság- és Társadalomföldrajz Tanszék. CD, 13 pages. .2012. "A geográfus Wallner Ernő helye a tudományban: a diskurzuselemzés lehetőségei" ['The place of the geographer Ernö Wallner in science: the possibilities of discourse analysis']. Soproni Szemle ['Sopron Review'] 66. 2: 143-155. . 2014. "Érzelmek a gazdaságföldrajzban: Fodor Ferenc vitája a Földrajzi Közleményekben" ['Emotions in Economic Geography: The Ferenc Fodor Debate in Geographical Review']. In Földrajz- és földtudomány az Eötvös Collegiumban. ['Geography and Earth Sciences at the Eötvös Collegium']. Ed. Róbert Györi. Budapest: Eötvös Collegium. 143-161.

Davis, Sasha. 2011. "East-West Discourse in Transylvania: Transitional Erdély, German-Western Siebenbürgen or Latin-Western Ardeal." In The East-West Discourse: Symbolic Geography and Its Consequences. Ed. Alexander Maxwell. Oxford: Peter Lang, 127-154. 
Jobbitt, Steven and Róbert Győri. "Introduction: Questions of Space and Place in Scholarship on Modern Hungary." Hungarian Cultural Studies. e-Journal of the American Hungarian Educators Association, Volume 7 (2014):

Eigler, Friederike. 2012. "Critical Approaches to Heimat and the 'Spatial Turn." New German Critique 39/1 (115): 27-48.

Erőss, Ágnes and Tátrai, Patrik. 2010. "Ethnic Features of Symbolic Appropriation of Public Space in Changing Geopolitical Frames - The Case of Oradea/Nagyvárad." Hungarian Geographical Bulletin 59/1: 51-68.

Fischer, Wladimir, Waltraud Heindl, Alexandra Millner \& Wolfgang Müller-Funk, eds. 2010. Grenzen und Räume in Österreich-Ungarn 1867-1918. Kulturwissenschaftliche Annäherungen ['Borders and Spaces in Austria-Hungary 1867-1918: Cultural Investigations and Evaluations']. Tübingen: Francke Verlag.

Fodor, Ferenc. 1935. "Történelmi és településföldrajz" ['Historical Geography and Urban and Settlement Geography']. Földrajzi Közlemények ['Geographical Review'] 63: 289-295.

Fodor, Mónika. 2014. "Narrative Trans-Ethnicity in the Correspondence of John Xántus and Spencer Fullerton Baird." In Mobile Narratives: Travel, Migration, and Transculturation. Eds. Eleftheria Arapoglou, Mónika Fodor, and Jopi Newman. New York and London: Routledge: 70-84.

Frisnyák, Sándor. 1990. Magyarország történeti földrajza ['Historical Geography of Hungary’]. Budapest: Tankönyvkiadó.

Gerő, András, and János Poór. 1997. Budapest: A History from Its Beginnings to 1998. Trans. Judit Zinner, Cecil D. Eby, and Nóra Arató. Boulder, CO: Social Science Monographs.

Glant, Tibor. 2013. Amerika, a csodák és csalódások földje. Az Amerikai Egyesült Államok képe a hosszú XIX. század magyar utazási irodalmában ['America, the Land of Wonders and Disappointments: The Picture of the United States of America in the Hungarian Travel Literature of the Long Nineteenth Century']. Debrecen: University of Debrecen Press.

Gyáni, Gábor. 1989. Women as Domestic Servants: The Case of Budapest, 1890-1940. New York: Institute on East Central Europe, Columbia UP. .2002. Parlor and Kitchen: Housing and Domestic Culture in Budapest, 1870 1940. Budapest: Central European Press.

. 2004. Identity and the Urban Experience: Fin-de-Siècle Budapest. Trans. Thomas J. DeKornfeld. Wayne, IN: Center for Hungarian Studies and Publications.

Gyimesi, Zoltán. 2011. "Thomas S. Kuhn gondolatainak szerepe a földrajztudomány történetének kontextualista elbeszélésében" ['The Relation of Thomas S. Kuhn's ideas to the contextualist account of the history of geography']. Tér és Társadalom ['Space and Society'] 25. 1: 81-99. . 2014. "The contested post-socialist rehabilitation of the past: The dual narrative and the republishing of Tibor Mendöl's 'Introduction to Geography." Hungarian Cultural Studies 7 (see current issue).

Győri, Róbert. 2001. "A magyar gazdaságföldrajz a két világháború között” ['Hungarian Economic Geography Between the World Wars']. In Geográfia az ezredfordulón. Regionális Tudományi Tanulmányok 6 ['Geography at the Turn of the Millenium. Studies in Regional Science 6.']. Ed. József Nemes Nagy. Budapest: Eötvös Loránd University, Department of Regional Geography: 61-83. 
Jobbitt, Steven and Róbert Győri. "Introduction: Questions of Space and Place in Scholarship on Modern Hungary." Hungarian Cultural Studies. e-Journal of the American Hungarian Educators Association, Volume 7 (2014):

- 2002. "A magyar történeti földrajz a két világháború közöttt" ['Hungarian Historical Geography Between the World Wars']. Földrajzi Közlemények ['Geographical Review'] 126. 1-4: 79-92. . 2009. “Tibor Mendöl.” In Geographers: Biobibliographical Studies 28. Ed. Charles W. J. Withers and Hayden Lorimer. London: Continuum: 39-54. - 2011. "A múlttal való tudományos leszámolás - Eötvös collegista geográfusok az 1950es években" ['Scientific Reckoning with the Past - Geographers in Eötvös Collegium in the 1950s']. In Lustrum. Solemnia aedificii a.D. MCMXI inaugurati ['Ceremony. Formalities of the Building Inaugurated in AD 1911']. Ed. László Horváth, Krisztina Laczkó, Károly Tóth and András Péterffy. Budapest: Typotex-Eötvös Collegium: 288311. . 2012. "A magyar lét geográfusa - 125 éve született Fodor Ferenc (1887-1962). Konferencia-beszámoló." ['The Geographer of Hungarian Being - Ferenc Fodor (18871962) Born 125 Years Ago. Conference Report']. Földrajzi Közlemények ['Geographical Review'] 136. 4: 461-463.

—. ed. Földrajz- és földtudomány az Eötvös Collegiumban ['Geography and Earth Sciences at the Eötvös Collegium']. Budapest: Eötvös Collegium.

Győri, Róbert and Ferenc, Gyuris. 2012. "The Sovietisation of Hungarian Geography, 19451960." Mitteilungen der Österreichischen Geographischen Gesellschaft ['Review of the Austrian Geographical Society'] 154: 107-128.

Gyuris, Ferenc. 2009. “A Teleki-iskola módszertani újításai a két világháború közötti magyar társadalomföldrajzban" ['Methodical innovations of the Teleki school in interwar Hungarian human geography']. In Tudós tanárok az Eötvös Collegiumban ['Scientist teachers in Eötvös Collegium']. Ed. Enikő Sepsi and Károly Tóth. Budapest: Ració: 138164. - 2014. "Egy tudományos alkotás története - a tudománytörténet megalkotása. Fodor Ferenc: A magyar földrajztudomány története" ['The history of a scientific work working out scientific history. Ferenc Fodor: The history of Hungarian geography']. In Földrajz- és földtudomány az Eötvös Collegiumban. ['Geography and Earth Sciences at the Eötvös Collegium']. Ed. Róbert Györi. Budapest: Eötvös Collegium: 163-194. . "Human Geography, Cartography, and Statistics: A Toolkit for Geopolitical Goals in Hungary until World War II." Hungarian Cultural Studies 7 (see current issue).

Gyuris, Ferenc and Györi, Róbert. 2013. "Sovietised Science at the Service of 'Socialist National Economy'. The Example of Hungarian Geography, 1945-1960." Berichte: Geographie und Landeskunde ['Review: Geography and Regional Studies'] 87.1: 7-25.

Hajdú, Zoltán. 1990-91. "A Tanyai Tanács története" ['The History of the Scattered Farm Council']. Alföldi Tanulmányok ['Alföld Studies'] 14: 105-124. . 1992. "Település- és településhálózat-fejlesztési politika Magyarországon az államszocializmus időszakában" ['Settlement Network and Urban Development Policy in Hungary during the Communism']. Földrajzi Közlemények ['Geographical Review'] 116.1-2: 29-37. . 2000. "A magyar földrajztudomány és a trianoni békeszerződés. 1918-1920" ['Hungarian Geography and the Trianon Peace Treaty']. Kisebbségkutatás ['Minorities Studies and Reviews']. 9. 2: 224-233. 
Jobbitt, Steven and Róbert Győri. "Introduction: Questions of Space and Place in Scholarship on Modern Hungary." Hungarian Cultural Studies. e-Journal of the American Hungarian Educators Association, Volume 7 (2014):

- 2006. "A szocialista természetátalakitás kérdései Magyarországon, 1948-1956.” [“The Socialist Transformation of Nature 1948-1956']. In Táj, környezet és társadalom. Ünnepi tanulmányok Keveiné Bárány Ilona professzor asszony tiszteletére ['Landscape, environment, society. Festschrift for Professor Ilona Keveiné Bárány']. Ed. Andrea Kiss, Gábor Mezösi and Zoltán Sümeghy. Szeged: SZTE Éghajlattani és Tájföldrajzi, Természetföldrajzi és Geoinformatikai Tanszék: 245-258.

- 2007. "Hungarian researches on the Southeast-European space (the Balkans): continuity, interruption or permanent re-start.” In Southeast-Europe: State Borders, Cross-Border Relations, Spatial Structures. Ed. Zoltán Hajdú, Iván Illés and Zoltán Raffay. Pécs: Centre for Regional Studies, Hungarian Academy of Sciences: 10-44.

— 2008. "Rónai András, a politikai földrajzos" ["András Rónai: a political geographer']. Földrajzi Értesitö ['Geographical Bulletin'] 57: 39-54.

Hanák, Péter. 1998. The Garden and the Workshop: Essays on the Cultural History of Vienna and Budapest. Princeton: Princeton UP.

Heffernan, Michael and Györi, Róbert. 2014. "Sándor Radó." In Geographers: Biobibliographical Studies 33. Ed. Charles W. J. Withers and Hayden Lorimer. London: Bloomsbury: 167-202.

Hofer, Tamás, ed. 1994. Hungarians Between "East" and "West": Three Essays on National Myths and Symbols. Budapest: Museum of Ethnography.

Jobbitt, Steven. 2008a. "Subterranean Dreaming: Hungarian Fantasies of European Integration and Redemption in Nimród Antal's Kontroll," Kinokultura, Special Issue no. 7: Hungarian Cinema (February): www.kinokultura.com/specials/7/kontroll

- 2008b. "A Geographer's Tale: Nation, Modernity, and the Negotiation of Self in Trianon Hungary, 1920-1960." Ph.D. Thesis, University of Toronto.

- 2011. "Playing the Part: Hungarian Boy Scouts and the Performance of Trauma in Interwar Hungary," AHEA: E-Journal of the American Hungarian Educator's Association, Vol. 4 (October): www.ahea.net/e-journal.

Kivelson, Valerie. 2006. Cartographies of Tsardom: The Land and Its Meaning in Seventeenth-Century Russia. Ithaca, NY: Cornell UP.

Knowles, A., Cole, T. J., \& Giordano, A. 2014. Geographies of the Holocaust. Bloomington, IN: Indiana UP.

Kürti, László. 2001. The Remote Borderland: Transylvania in the Hungarian Imagination. Albany: State University of New York Press.

Lampland, Martha. 1994. "Family Portraits: gendered Images of the Nation in Nineteenth Century Hungary." East European Politics and Societies 8/2 (Spring): 287-316

Lettrich, Edit. 1968. Kecskemét és tanyavilága ['Kecskemét and the town's scattered farms']. Budapest: Akadémiai.

Livingstone, David. N. 1992. The Geographical Tradition. Episodes in the History of a Contested Enterprise. Chicago: Chicago University Press.

- 2003. Putting Science in its Place: Geographies of Scientific Knowledge. Oxford: Blackwell.

Maxwell, Alexander. 2011. The East-West Discourse: Symbolic Geography and Its Consequences. Oxford: Peter Lang.

Melegh, Attila. 2006. On the East-West Slope: Globalization, Nationalism, Racism and 
Jobbitt, Steven and Róbert Győri. "Introduction: Questions of Space and Place in Scholarship on Modern Hungary." Hungarian Cultural Studies. e-Journal of the American Hungarian Educators Association, Volume 7 (2014):

http://ahea.pitt.edu DOI: 10.5195/ahea.2014.176

Discourses on Eastern Europe. Budapest: Central European UP.

Mendöl, Tibor. n.d. (1938). "Településtörténet, településföldrajz, történeti földrajz” ['Urban and Settlement History, Urban and Settlement Geography, Historical Geography']. In:

Emlékkönyv Szentpétery Imre születése hatvanadik évfordulójának ünnepére ['Festschrift for the Sixtieth Birthday of Imre Szentpéteri']. Budapest: 312-334.

—. 1963. Általános településfölrajz ['Settlement and Urban Geography']. Budapest: Akadémiai.

Molnár, Virág. 2013. Building the State: Architecture, Politics, and State Formation in Postwar Central Europe. London and New York: Routledge.

Nemes, Robert, 2005. The Once and Future Budapest. DeKalb (IL): Northern Illinois UP.

—. 2012. "Obstacles to Nationalization on the Hungarian-Romanian Language Frontier." Austrian History Yearbook 43: 28-44.

Nemes, Robert, and Daniel Unowsky, eds. 2014. Sites of European Antisemitism in the Age of Mass Politics, 1880-1918. Brandeis UP.

Neuberger, Mary. 2004. The Orient Within: Muslim Minorities and the Negotiation of Nationhood in Modern Bulgaria. Ithaca: Cornell UP.

Palaczki, Botond. 2013. "Földrajz és nemzetépítés Közép- és Kelet-Közép-Európában. Nemzetközi konferencia az ELTE Eötvös József Collegiumban" ['Geography and Nation Building in Central and East Central Europe. International conference at ELTE Eötvös József Collegium']. Tér és Társadalom 27. 4: 215-220.

Probáld, Ferenc. 2014. “Győri Róbert (szerk.): Földrajz- és földtudomány az Eötvös Collegiumban - recenzió" ['Geography and Earth Sciences at the Eötvös Collegium ed. Róbert Györi - book review']. Földrajzi Közlemények ['Geographical Review'] 138. 4: 358-360.

Rac, Katalin F. 2014. "Orientalism for the Nation: Jews and Oriental Scholarship in Modern Hungary." Ph.D. Thesis, University of Florida.

Said, Edward. 1978. Orientalism: Western Conceptions of the Orient. New York: Pantheon.

Sahlins, Peter. 1989. Boundaries: The Making of France and Spain in the Pyrenees. Berkeley: University of California Press.

Seegel, Steven. 2012. Mapping Europe's Borderlands: Russian Cartography in the Age of Empire. Chicago: University of Chicago Press.

Schorske, Carl E. 1981. Fin-de-Siècle Vienna: Politics and Culture. New York: Vintage.

Thorstensen, Erik. 2012. "The Places of Memory in a Square of Monuments:

Conceptions of Past, Freedom and History at Szabadság Tér." AHEA: E-journal of the

American Hungarian Educators Association, Volume 5: http://ahea.net/e-journal/volume$5-2012$.

Timár, Judit and Éva G. Fekete. 2010. "Fighting for Recognition: Feminist Geography in East-Central Europe." Gender, Place \& Culture: A Journal of Feminist Geography 17/6: 775-790.

Todorova, Maria. 1997. Imagining the Balkans. New York: Oxford UP.

Tolnai, Gábor. 2013. "Geography and Nation Building in Central and East Central Europenemzetközi konferencia az ELTE Eötvös József Collegiumban” ['Geography and Nation 
Jobbitt, Steven and Róbert Győri. "Introduction: Questions of Space and Place in Scholarship on Modern Hungary." Hungarian Cultural Studies. e-Journal of the American Hungarian Educators Association, Volume 7 (2014):

Building in Central and East Central Europe-international conference at ELTE Eötvös József Collegium']. Földrajzi Közlemények ['Geographical Review'] 137. 4: 423-425.

Turda, Marius. 2007. "The Nation as Object: Race, Blood, and Biopolitics in Interwar Romania." Slavic Review 66/3 (Fall): 413-441. . 2013. "Imagined Geographies of Race: Hungary and Romania, 1900 1940." In Hungary and Romania Beyond National Narratives: Comparisons and Entanglements. Eds. Anders E.B.Blomqvist, Constantin Iordachi, and Balázs Trencsényi. Oxford: Peter Lang, 293-320.

Veres, Madalina-Valeria. 2012. "Putting Transylvania on the Map: Cartography and Enlightened Absolutism in the Habsburg Monarchy," Austrian History Yearbook 43 (May): 141-164. 2014. "Redefining Imperial Borders: Marking the Eastern Border of the Habsburg Monarchy in the Second Half of the Eighteenth Century." In History of Cartography, Lecture Notes 3 in Geoinformation and Cartography. Eds. E. Liebenberg et al. Berlin and Heidelberg: Springer-Verlag: 1-23.

Vida, István Kornél. 2013. "The New World is An Other World: Hungarian Transatlantic Emigrants' Handbooks and Guidebooks, 1903-1939" AHEA: E-Journal of the American Hungarian Educators Association, Vol. 6. http://ahea.net/e-journal/volume-6-2013/8. . "Death of a Nation? Debating the Great Transatlantic Emigration from Hungary, 19001914." Hungarian Cultural Studies 7 (see current issue).

Wallner, Ernő. 1958. "Paks településképe" ['Urban Landscape of Paks']. Földrajzi Közlemények ['Geographical Review'] 82. 1:1-26.

Winichakul, Thongchai. Siam Mapped: A History of the Geo-Body of a Nation. Honolulu: University of Hawaii Press.

Withers, Charles W. J. 2001. Geography, Science and National Identity: Scotland since 1520. Cambridge: Cambridge University Press.

- 2010. Geography and Science in Britain. 1831-1939. Manchester and New York: Manchester University Press.

Wolff, Larry. 1994. Inventing Eastern Europe: The Map of Civilization on the Mind of the Enlightenment. Stanford: Stanford UP. 